\title{
Effects of Brand Experience on Brand Loyalty in Fashion Retail Business
}

\author{
PHAM THI LAN HUONG \\ The University Of Danang - University Of Economics - phamlanhuong2008@gmail.com \\ NGO THI HONG \\ College of Commerce - ngohong.dn@gmail.com \\ TRAN TRIEU KHAI \\ The University Of Danang - University Of Economics - trantrieukhai@ yahoo.com
}

\section{ARTICLE INFO ABSTRACT}

Article history:

Received:

Oct. 102015

Received in revised form:

Dec. 252015

Accepted:

June 202016

Keywords:

Brand experience, fashion brand experience, brand loyalty.
In the retail environment where fierce competition pressure can be perceived, the role of brand experience becomes increasingly important. This study addresses the theory of brand experience and verifies its relationship with brand loyalty as well as its scales and model in the fashion retail industry. With the data collected from direct personal interviews with 285 consumers aged between 18-35 of such two fashion brands as Ninomax and Blue Exchange in Danang City, the findings suggest positive effects of the constructs of brand experience concerning sense, emotion, cognition, and relation on the two concepts of shopping experience and product experience, both of which, in turn, have positive effects on brand personality, brand trust, brand satisfaction, and brand loyalty. Particularly, brand trust is found to have no effect on brand loyalty. 


\section{Problem statement}

Under the harsh pressure from fierce competition, to gain competitiveness, firms not only aim to advance their technologies to improve the quality and lower the product prices but also focus on research and marketing activities. Particularly, changes in marketing perception that allow for experiences that fit the market trend, along with increasing marketing funding, arouse great concern from managers. A marketing strategy that stimulates customers' experiences is an inevitable trend as adopted by marketers in the world.

Brand experience in forecasting consumer behavior is crucial, regarded as intriguing and memorable know-how which considerably impacts on brand loyalty. Investigations into this topic, however, are still scarce. As one of the first related studies, Brakus et al. (2009) addressed brand experience and its direct and indirect effects on customer satisfaction and loyalty through brand personality. In Vietnam the somewhat novel concepts of 'customer experience' and 'customer's brand experience' have not been extensively examined both theoretically and empirically; thus, research into the brand experience in fashion retail industry is appropriate and necessary. In this paper we adapt the original scales suggested in earlier studies and verify and/or re-evaluate them in order to construct a suitable model for the context of Vietnam, which is, in turn, believed to be a scientific contribution to be made.

\section{Theoretical bases and methodology}

\subsection{Theoretical background}

\subsubsection{Brand experience}

Customer experience is defined as internal and subjective reactions of customers when they interact directly or indirectly with the company, as well as its products, brand, and stores. Schmitt (1999) categorized customer experience into five groups: sense, feel, think, act, and relate.

According to Brakus et al. (2009), brand experience is internal and subjective reactions of customers (sensations, feelings, cognitions) and "behavioral responses evoked by brand-related stimuli that are part of a brand's design and identity, packaging, communications, and environments." It is thus regarded as a multi-criteria concept that 
comprises the customer's senses, feelings, thoughts, and behavior toward a specific brand (Iglesias et al., 2011; Brakus et al., 2009).

\subsubsection{Constructs of brand experience}

Sensory experience: Sensing a product is essential to consumers, particularly in the retail industry. Interests in the aesthetics of the product (such as its colors, texture, and design) motivate consumers to try and decide on purchase of the product. The consumer's positive sensory experiences of a fashion brand assist in identification of a good brand.

Affective experience: Consumers' emotions do have a connection with product experience when they try out a range of fashion products. Holbrook (1986) and Mano and Oliver (1993) asserted that exhilaration and joyfulness exert the greatest effect on consumer experience. Consumers engaging themselves in high-end shopping of fashion products tend to have a desire to demonstrate positive affective experience like cheerfulness, contentment, or relaxation (Park et al., 2006) to satisfy their shopping motives.

Intellectual experience: Product experiences possibly affect consumers' experience or what they learn about the product. Learning orientations and shopping experience contribute to fashion consumers' clear perception of the brand.

Behavioral experience: Little attention has been paid to this dimension in foreign research. Behavioral experience can be enjoyed via using a brand. On the other hand, not only does the apparel reflect on the wearer's fashion style but it also conveys his or her lifestyle. High-class costumes navigate both acceptable behavior of the wearer and his or her communication style perceived by others.

Relational experience: This refers to social experience, which creates value for customers by providing social identity and awareness of social cohesion. Experiences of physical products are crucial to the consumer in order to establish relation to the products.

2.1.3. Types of brand experience

\section{Product experience}

Product experience takes place during the consumer's search, purchase, consumption, and evaluation of the product (Brakus et al., 2009). This occurs when the customer 
interacts with the product directly (Hoch \& Ha, 1986) or indirectly through advertisements (Hoch \& Ha, 1986; Schmitt, 1999).

\section{Shopping experience}

Consumers undergo shopping and service experiences in their interactions with the physical environment, employees, and services available in a store (Brakus et al., 2009). Kerin et al. (1992), in clarifying perceived value by a consumer of a retail store, indicated that perception of shopping experience in the store is more critical than that of price or quality. The images stored of a retailer may damage its brand when consumers have negative experiences of the store. Interactions between customers and sales departments may encourage awareness of the product or service of the brand. Creating positive shopping experiences is likely to bring about positive behavior and, even more than that, customer satisfaction and loyalty toward the brand.

2.1.4. Research model and proposed hypotheses

The researches done outside Vietnam on the similar topic mostly examined dimensions of brand experience as a whole. Brakus's (2009) model provides a basis for multiple investigations into brand experience; the model, nevertheless, centers on its four dimensions emphasizing effects on consumer satisfaction and loyalty with no clear differentiation of product and shopping experiences. In another study Evans (2011) approached brand experience through product experience and shopping experience. While Brakus et al. (2009) measured brand experience with its influence through brand personality associations, these were not addressed by Evans (2011).

Overall, Brakus's (2009) technique has been commonly adapted, but its downside is a lack of comprehensive evaluation of brand experience types, whereas this fact becomes a focal point in Evans (2011). This study, for this reason, employs a combination of both models as a cornerstone of our own. 


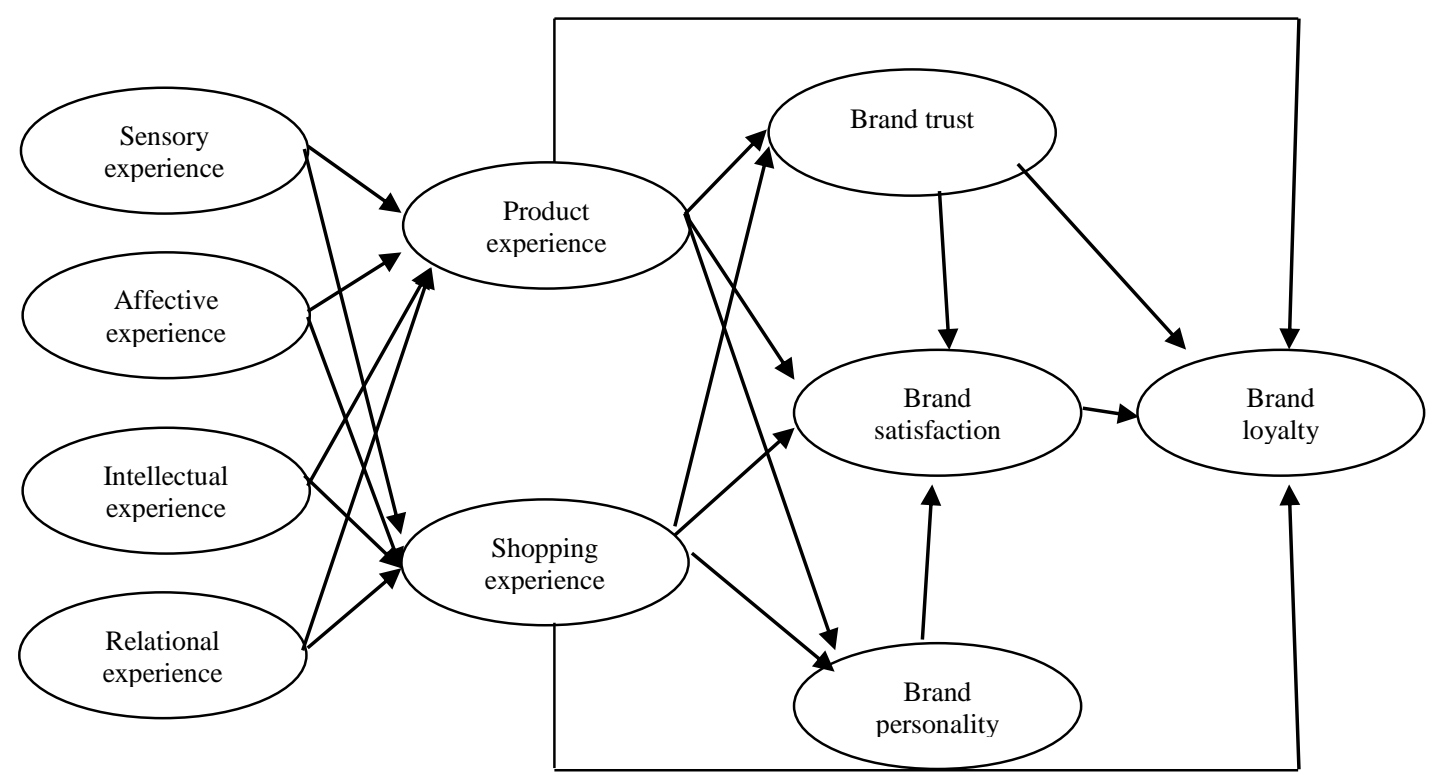

Figure 1. Proposed research model

\section{Research hypotheses}

Sensory experience: Jones et al. (2010) demonstrated the relation between sensory experience of the retailer and its brand, and based on the experiences, consumers enjoy hedonic values in the shopping process. According to Brakus et al. (2009) and Nysveen et al. (2012), sensory experience produces a positive impact on brand satisfaction and brand loyalty. Evans (2011) argued that it positively affects both product experience and shopping experience. Accordingly:

Hla: Sensory experience positively relates to product experience.

H1b: Sensory experience positively relates to shopping experience.

Affective experience: Emotion has association with product experience when fashion consumer uses the fashion products. Holbrook (1986) and Mano and Oliver (1993) verified that excitement and joyfulness have the most powerful impact on consumer's experience of the product. Lee et al. (2007) and Evans (2011) agreed on positive effects of affective experience on product and shopping experiences. Accordingly:

H2a: Affective experience positively relates to product experience.

$H 2 b$ : Affective experience positively relates to shopping experience. 
Intellectual experience: The experience of this kind enables consumers to be keenly aware of a wide variety of fashion brands and also permits identification of elegant, luxurious, high-class, sophisticated, and stylish ones. Kim and Lennon (2010) confirmed the influence of shopping environment on intellectual experience. Thus, the following hypotheses can be formulated:

H3a: Intellectual experience positively relates to product experience.

$H 3 b$ : Intellectual experience positively relates to shopping experience.

Relational experience: Physical product experiences are significant to consumers in their establishing relations with the fashion brand. Once consumers have undergone product experiences and have positive feelings about the product, they will make a purchase without trying on any others. It is likely for one to see a set of clothing and have prompt association with a group of users of that product (Grant, 2005). Evans (2011) revealed positive effects of relational experience on product and shopping experiences. Therefore, we propose the following:

H4a: Relational experience positively relates to product experience.

H4b: Relational experience positively relates to shopping experience.

Associations among types of brand experience, constructs of brand personality, brand trust, and brand satisfaction and brand loyalty:

In the course of brand development, the linkage between the brand and customers is essential. Brand experience enables brand trust and loyalty by establishing many links with emotions, settings, and contact environment between customers and the product and/or the brand (Sahin et al., 2011). A positive association between brand experience and brand loyalty has been pinpointed in quite a few studies, including Horppu et al. (2008), Brakus et al. (2009), Kim and Lennon (2010), and Evans (2011). Chaudhuni and Holbook (2001) exemplified the positive relationship between brand experience and brand trust, and customers have a tendency to repeat their purchase when having a faith in the brand or having gone through positive experiences of it. Moreover, brand experience is positively related to brand personality as indicated by Brakus et al. (2009) and Choi et al. (2011). The following hypotheses, therefore, can be constructed:

H5a: Product experience positively relates to brand trust.

H5b: Product experience positively relates to brand personality.

H5c: Product experience positively relates to brand satisfaction. 
H6a: Shopping experience positively relates to brand trust.

H6b: Shopping experience positively relates to brand personality.

H6c: Shopping experience positively relates to brand satisfaction.

H7: Brand trust positively relates to brand satisfaction.

H8: Brand personality positively relates to brand satisfaction.

H9: Brand satisfaction positively relates to brand loyalty.

H10: Brand trust positively relates to brand loyalty.

H11: Product experience positively relates to brand loyalty.

H12: Shopping experience positively relates to brand loyalty.

\subsection{Methodology}

This paper employs quantitative method with the questionnaire constructed using different scales as defined in different studies: sensory, affective, and intellectual experiences and brand personality (Brakus, 2009); relational, product, and shopping experiences (Evans, 2011); brand trust (Choi et al., 2011); brand loyalty (Choi et al., 2011; Evans, 2011). A pilot survey was conducted on 20 consumers with adjustment of indicators to suit Vietnamese's consumption habits. We then carried out a formal survey on 285 consumers aged 18-35 in Danang City, who were to give feedback on experiences of two popular fashion brands: Ninomax and Blue Exchange after their shopping for and using these. SPSS and Amos were used for data analysis.

\section{Results and discussion}

\subsection{Sample description}

During the data collection, 258 questionnaire responses were retrieved. Data screening and cleaning allowed us to eliminate four responses due to their inconsistency, thus making a total of 256 valid ones for analysis, including 124 considering Ninomax, and 130, Blue Exchange. Most respondents are aged between 18 and 25 (76\%), whereas those aged 26-35 accounts for $24 \%$.

Income levels among respondents are not equally allocated. Low income earners (below VND1mil.) make up 32\%, whereas the low-middle income group (VND1-3mil.) reaches 36\%. Respondents with high-middle income (VND3-5mil.) and rather high/high income (VND5-10mil. and over VND10mil.) account for 19\% and 13\% 
respectively. This relatively reflects the income state of Danang's and Vietnam's citizens. The proportions of respondents in terms of gender are quite similarly distributed; particularly, female participants are found to dominate (60\%).

\subsection{Testing for reliability of the scales and model}

The testing results for reliability of the scales and suitability of the model are presented in Table 1.

\section{Table 1}

Preliminary test of the scales

\begin{tabular}{|c|c|c|c|c|c|c|c|c|}
\hline Variable & $\begin{array}{l}\text { Factor } \\
\text { loading }\end{array}$ & $\begin{array}{l}\text { Common } \\
\text { variance }\end{array}$ & MSA & $\begin{array}{l}\text { Corrected item- } \\
\text { total correlation }\end{array}$ & $\begin{array}{c}\text { CA if } \\
\text { item } \\
\text { deleted }\end{array}$ & CA & Eigenvalue & $\begin{array}{c}\% \text { of } \\
\text { variance }\end{array}$ \\
\hline
\end{tabular}

Dimensions of brand experience

$\mathrm{KMO}=0.787-$ Bartlett test: $\chi^{2}=632.5 ; \mathrm{df}=55 ;$ Sig. $=0.000-$ Total variance explained $=64.7 \%$

\begin{tabular}{lllllllll}
\hline CG1 & 0.85 & 0.76 & 0.73 & 0.58 & 0.50 & & & \\
CG2 & 0.80 & 0.71 & 0.72 & 0.51 & 0.58 & 0.69 & 1.3 & 15.9 \\
CG3 & 0.46 & 0.56 & 0.85 & 0.42 & 0.70 & & & \\
\hline TC1 & 0.71 & 0.61 & 0.86 & 0.52 & 0.51 & & & 18.9 \\
TC2 & 0.79 & 0.65 & 0.83 & 0.45 & 0.60 & 0.66 & 3.6 & \\
TC3 & 0.62 & 0.50 & 0.82 & 0.46 & 0.59 & & & 16.5 \\
\hline SN1 & 0.75 & 0.68 & 0.78 & 0.46 & 0.54 & & & \\
SN2 & 0.85 & 0.75 & 0.72 & 0.53 & 0.44 & 0.65 & 1.3 & \\
SN3 & 0.54 & 0.49 & 0.85 & 0.38 & 0.65 & & & \\
\hline QH1 & 0.84 & 0.72 & 0.69 & 0.38 & - & 0.55 & 1.0 & \\
QH2 & 0.75 & 0.67 & 0.76 & 0.38 & - & & & \\
\hline Typs of & & & $0 \times 13$ & & & & \\
\hline
\end{tabular}

Types of brand experience

$\mathrm{KMO}=0.831-$ Bartlett test: $\chi^{2}=627.0 ; \mathrm{df}=45 ;$ Sig. $=0.000-$ Total variance explained $=50.0 \%$

\begin{tabular}{lllllllll}
\hline SP1 & 0.73 & 0.57 & 0.81 & 0.58 & 0.69 & & & \\
SP2 & 0.76 & 0.58 & 0.81 & 0.58 & 0.69 & & &
\end{tabular}




\begin{tabular}{|c|c|c|c|c|c|c|c|c|}
\hline Variable & $\begin{array}{l}\text { Factor } \\
\text { loading }\end{array}$ & $\begin{array}{l}\text { Common } \\
\text { variance }\end{array}$ & MSA & $\begin{array}{l}\text { Corrected item- } \\
\text { total correlation }\end{array}$ & $\begin{array}{c}\mathrm{CA} \text { if } \\
\text { item } \\
\text { deleted }\end{array}$ & $\mathrm{CA}$ & Eigenvalue & $\begin{array}{c}\% \text { of } \\
\text { variance }\end{array}$ \\
\hline SP3 & 0.60 & 0.43 & 0.88 & 0.47 & 0.73 & & & \\
\hline SP4 & 0.63 & 0.41 & 0.87 & 0.45 & 0.74 & & & \\
\hline SP5 & 0.68 & 0.50 & 0.88 & 0.54 & 0.71 & & & \\
\hline $\mathrm{CH} 1$ & 0.50 & 0.43 & 0.84 & 0.45 & 0.67 & & & \\
\hline $\mathrm{CH} 2$ & 0.82 & 0.67 & 0.73 & 0.48 & 0.65 & & & \\
\hline $\mathrm{CH} 3$ & 0.72 & 0.53 & 0.78 & 0.43 & 0.67 & 0.71 & 1.3 & 21.9 \\
\hline $\mathrm{CH} 4$ & 0.59 & 0.52 & 0.85 & 0.55 & 0.63 & & & \\
\hline CH5 & 0.50 & 0.37 & 0.84 & 0.43 & 0.67 & & & \\
\hline
\end{tabular}

Intermediate factors

KMO $=0.872-$ Bartlett test: $\chi^{2}=1278.0 ; \mathrm{df}=105 ;$ Sig. $=0.000-$ Total variance explained $=54.6 \%$

\begin{tabular}{|c|c|c|c|c|c|c|c|c|}
\hline BP2 & 0.72 & 0.58 & 0.83 & 0.54 & 0.63 & \multirow{4}{*}{0.71} & \multirow{4}{*}{1.3} & \multirow{4}{*}{15.0} \\
\hline BP3 & 0.73 & 0.59 & 0.84 & 0.54 & 0.63 & & & \\
\hline BP4 & 0.52 & 0.50 & 0.91 & 0.45 & 0.68 & & & \\
\hline BP5 & 0.70 & 0.58 & 0.87 & 0.48 & 0.66 & & & \\
\hline NT1 & 0.66 & 0.63 & 0.84 & 0.58 & 0.75 & \multirow{5}{*}{0.79} & \multirow{5}{*}{1.5} & \multirow{5}{*}{19.3} \\
\hline NT2 & 0.76 & 0.68 & 0.82 & 0.65 & 0.73 & & & \\
\hline NT4 & 0.63 & 0.47 & 0.87 & 0.52 & 0.77 & & & \\
\hline NT5 & 0.62 & 0.52 & 0.86 & 0.57 & 0.75 & & & \\
\hline NT6 & 0.72 & 0.56 & 0.90 & 0.52 & 0.77 & & & \\
\hline HL1 & 0.65 & 0.60 & 0.85 & 0.62 & 0.75 & \multirow{5}{*}{0.80} & \multirow{5}{*}{5.4} & \multirow{5}{*}{20.3} \\
\hline HL2 & 0.65 & 0.53 & 0.90 & 0.59 & 0.76 & & & \\
\hline HL3 & 0.62 & 0.41 & 0.91 & 0.41 & 0.80 & & & \\
\hline HL4 & 0.76 & 0.59 & 0.89 & 0.56 & 0.77 & & & \\
\hline HL5 & 0.63 & 0.52 & 0.88 & 0.60 & 0.76 & & & \\
\hline
\end{tabular}




\begin{tabular}{|c|c|c|c|c|c|c|c|c|}
\hline Variable & $\begin{array}{l}\text { Factor } \\
\text { loading }\end{array}$ & $\begin{array}{l}\text { Common } \\
\text { variance }\end{array}$ & MSA & $\begin{array}{l}\text { Corrected item- } \\
\text { total correlation }\end{array}$ & $\begin{array}{l}\text { CA if } \\
\text { item } \\
\text { deleted }\end{array}$ & $\mathrm{CA}$ & Eigenvalue & $\begin{array}{c}\% \text { of } \\
\text { variance }\end{array}$ \\
\hline NT3 & 0.56 & 0.44 & 0.91 & 0.55 & 0.77 & & & \\
\hline \multicolumn{9}{|c|}{ Results: Brand loyalty } \\
\hline \multicolumn{9}{|c|}{$\mathrm{KMO}=0.789-$ Bartlett test: $\chi^{2}=410.2 ; \mathrm{df}=10 ;$ Sig. $=0.000-$ Total variance explained $=56.7 \%$} \\
\hline TT1 & 0.61 & 0.37 & 0.88 & 0.45 & 0.81 & & & \\
\hline TT2 & 0.82 & 0.67 & 0.76 & 0.66 & 0.74 & & & \\
\hline TT3 & 0.74 & 0.55 & 0.76 & 0.57 & 0.77 & 0.80 & 2.8 & 56.7 \\
\hline TT4 & 0.79 & 0.63 & 0.81 & 0.64 & 0.75 & & & \\
\hline TT5 & 0.79 & 0.62 & 0.78 & 0.64 & 0.75 & & & \\
\hline
\end{tabular}

The testing results of the model are summarized in Table 2.

\section{Table 2}

Results of model tests

\begin{tabular}{|c|c|c|c|c|c|c|c|c|}
\hline & $\begin{array}{l}\text { Path } \\
\text { coef. }\end{array}$ & Std. err. & $\mathrm{T}$ & Sig & Tolerance & VIF & $\mathrm{R}^{2}$ & $\begin{array}{c}\text { Adjusted } \\
\mathrm{R}^{2}\end{array}$ \\
\hline SEN. EXP. $\rightarrow$ PRO. EXP. & 0.36 & 0.06 & 5.86 & $* * *$ & 0.76 & 1.32 & \multirow{4}{*}{$41.4 \%$} & \multirow{4}{*}{$40.5 \%$} \\
\hline AFF. EXP. $\rightarrow$ PRO. EXP. & 0.15 & 0.06 & 2.49 & $* *$ & 0.70 & 1.43 & & \\
\hline INT. EXP. $\rightarrow$ PRO. EXP. & 0.13 & 0.05 & 2.45 & $* *$ & 0.78 & 1.28 & & \\
\hline REL. EXP. $\rightarrow$ PRO. EXP. & 0.25 & 0.06 & 4.42 & $* * *$ & 0.87 & 1.15 & & \\
\hline SEN. EXP. $\rightarrow$ SHO. EXP. & 0.33 & 0.06 & 5.66 & $* * *$ & 0.76 & 1.32 & \multirow{4}{*}{$35.1 \%$} & \multirow{4}{*}{$34.1 \%$} \\
\hline AFF. EXP. $\rightarrow$ SHO. EXP. & 0.02 & 0.07 & 0.31 & NS & 0.70 & 1.43 & & \\
\hline INT. EXP. $\rightarrow$ SHO. EXP. & 0.13 & 0.06 & 2.26 & $* *$ & 0.78 & 1.28 & & \\
\hline REL. EXP. $\rightarrow$ SHO. EXP. & 0.33 & 0.06 & 5.86 & $* * *$ & 0.87 & 1.15 & & \\
\hline PRO. EXP. $\rightarrow$ BRA. PER. & 0.29 & 0.06 & 4.49 & $* * *$ & 0.70 & 1.42 & \multirow{2}{*}{$26.2 \%$} & \multirow{2}{*}{$25.6 \%$} \\
\hline SHO. EXP. $\rightarrow$ BRA. PER. & 0.29 & 0.07 & 3.93 & $* * *$ & 0.70 & 1.42 & & \\
\hline PRO. EXP. $\rightarrow$ BRA. TRU. & 0.32 & 0.07 & 4.58 & $* * *$ & 0.70 & 1.42 & $29.1 \%$ & $28.5 \%$ \\
\hline
\end{tabular}




\begin{tabular}{lllllllll} 
SHO. EXP. $\rightarrow$ BRA. TRU. & 0.29 & 0.09 & 3.40 & $* * *$ & 0.70 & 1.42 & & \\
\hline PRO. EXP. $\rightarrow$ BRA. SAT. & 0.39 & 0.06 & 6.81 & $* * *$ & 0.62 & 1.62 & & \\
SHO. EXP. $\rightarrow$ BRA. SAT. & 0.17 & 0.06 & 2.72 & $* * *$ & 0.62 & 1.61 & & \\
BRA. PER. $\rightarrow$ BRA. SAT. & 0.18 & 0.06 & 3.24 & $* * *$ & 0.67 & 1.50 & & \\
BRA. TRU. $\rightarrow$ BRA. SAT. & 0.19 & 0.06 & 3.15 & $* * *$ & 0.64 & 1.56 & & \\
\hline PRO. EXP. $\rightarrow$ BRA. LOY. & 0.25 & 0.07 & 3.40 & $* * *$ & 0.51 & 1.94 & & \\
SHO. EXP. $\rightarrow$ BRA. LOY. & 0.22 & 0.06 & 3.81 & $* * *$ & 0.61 & 1.63 & & \\
BRA. TRU. $\rightarrow$ BRA. LOY. & 0.03 & 0.06 & 0.57 & NS & 0.65 & 1.54 & & \\
BRA. SAT. $\rightarrow$ BRA. LOY. & 0.33 & 0.08 & 4.15 & $* * *$ & 0.47 & 2.11 & & \\
\hline Mean & & & & & & & $39.1 \%$ & $38.5 \%$ \\
\hline
\end{tabular}

Notes: $* * * \mathrm{p}<0.01 \quad * * \mathrm{p}<0.05 \quad * \mathrm{p}<0.1 \quad[\mathrm{NS}] \mathrm{p}>=0.1$

As indicated by the results of Table 2, all the brand experience constructs are positively related to the two types of brand experience (product and shopping experiences), except for affective experience which shows no effect on shopping experience $(\beta=0.02$, Sig.>0.1). Among these dimensions, sensory and relational experiences exert the most powerful and positive impacts on the two types ( $\beta$ SEN. EXP. --> PRO. EXP. $=0.36 ; \beta$ REL. EXP. --> PRO. EXP. $=0.25 ; \beta$ SEN. EXP. $-\rightarrow>$ SHO. EXP. $=\beta$ REL. EXP. $->>$ SHO. EXP. $=$ $0.33)$, whereas the influences of sensory and intellectual experiences are less significant $(\beta$ AFF. EXP. ->> PRO. EXP. $=0.15 ; \beta$ INT. EXP. $->$ PRO. EXP. $=\beta$ INT. EXP. --> SHO. EXP. $=0.13)$.

The two types of brand experience, furthermore, have positive and profound effects on brand personality ( $\beta=0.29$ for both), on brand trust $(\beta=0.32$ for product experience and $\beta=0.29$ for shopping experience), and also on brand satisfaction and loyalty. The product experience itself has the most powerful impact on brand satisfaction $(\beta=0.39)$; its level is much higher than brand personality $(\beta=0.18)$ and brand trust $(\beta=0.19)$. Nevertheless, the impact of shopping experience $(\beta=0.17)$ is found to be weaker than that of product experience on brand satisfaction.

Considering the factors affecting brand loyalty, the level of brand satisfaction impact remains the highest $(\beta=0.33)$, followed by product experience $(\beta=0.25)$ and shopping experience $(\beta=0.22)$. No effect of brand trust is found on brand loyalty $(\beta=0.03$, Sig.>0.1). 


\section{Evaluating the suitability of the model}

Brand experience dimensions explain $41 \%$ and $35 \%$ of variance in product experience and shopping experience, respectively. Next, these two types of brand experience explain $26 \%$ and $29 \%$ of variance in brand personality and brand trust, respectively. Taking together, two brand experience types, together with brand trust and personality, explain approximately 55\% of variance in brand satisfaction. Finally, $49 \%$ of variance in brand loyalty can be explained by brand experience, brand trust, and brand satisfaction. Accordingly, regarding the capability to forecast brand loyalty, the research model explains nearly half the level of its variance, thereby suggesting a well-developed model.

The result for $G o F=\sqrt{0.571 \times 0.385}=0.468$ reveals a high value $(>0.36)$, which indicates that the model satisfies criteria of reliability along with its great explanatory ability.

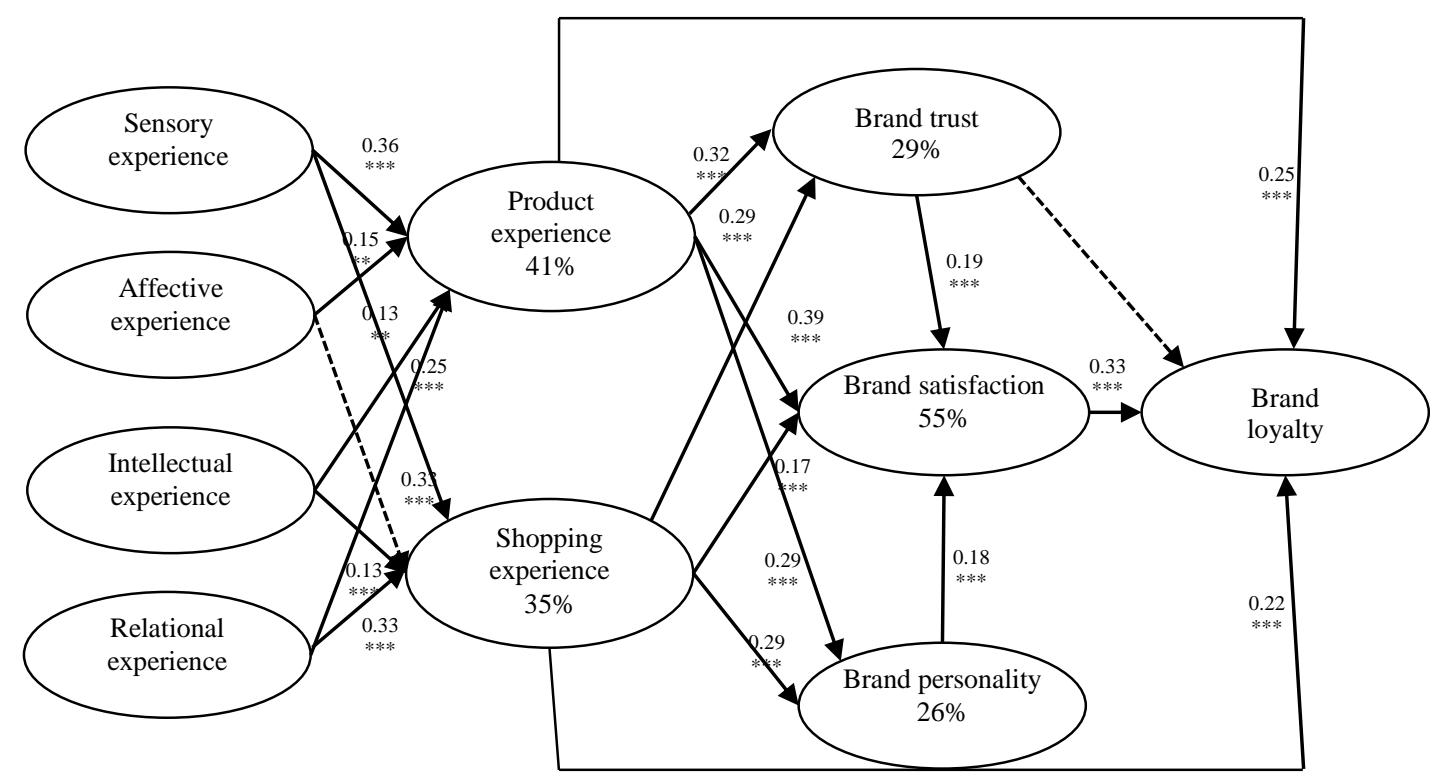

Figure 2. Results of model testing

From the testing results in Figure 2, all the proposed hypotheses are accepted, except for the one on the effect of brand trust on brand loyalty, which is rejected (Table 3). 


\section{Table 3}

Results of hypotheses testing

\begin{tabular}{ll}
\hline Hypothesis & Result \\
\hline H1a: Sensory experience positively relates to product experience. & Accepted \\
H1b: Sensory experience positively relates to shopping experience. & \\
H2a: Affective experience positively relates to product experience. & Accepted \\
H2b: Affective experience positively relates to shopping experience. & \\
H3a: Intellectual experience positively relates to product experience. & \\
H3b: Intellectual experience positively relates to shopping experience. & Accepted \\
H4a: Relational experience positively relates to product experience. & \\
H4b: Relational experience positively relates to shopping experience. & \\
H5a: Product experience positively relates to brand trust. & Accepted \\
H5b: Product experience positively relates to brand personality. & \\
H5c: Product experience positively relates to brand satisfaction. & \\
H6a: Shopping experience positively relates to brand trust. \\
H6b: Shopping experience positively relates to brand personality. \\
H6c: Shopping experience positively relates to brand satisfaction. \\
$\begin{array}{l}\text { H7: Brand trust positively relates to brand satisfaction. } \\
\text { H8: Brand personality positively relates to brand satisfaction. } \\
\text { H9: Brand satisfaction positively relates to brand loyalty. } \\
\text { H10: Brand trust positively relates to brand loyalty. } \\
\text { H11: Product experience positively relates to brand loyalty. } \\
\text { H12: Shopping experience positively relates to brand loyalty. }\end{array}$ \\
\hline
\end{tabular}

\subsection{Discussion of results}

The empirical results suggest that there exist positive relationships between brand experience types and brand loyalty as well as these and other intermediate factors such as brand trust, personality, and satisfaction. These results are similar to those of researches in other countries, including Evans (2011) conducted in the fashion industry. This once again demonstrates the reliability of the scales as verified in Vietnam. 
Concerning dimensions of brand experience that consist of sensory, affective, intellectual, and relational experiences, we figure out that the impact of sensory experience on brand experience types is far greater than that of the others. Meanwhile, product experience has more significant effects on intermediate factors and brand loyalty than shopping experience.

As have been indicated, the hypothesis on the relation between brand trust and brand loyalty is rejected, which is consistent with the outcome of Choi et al. (2011). This may be due to the fact that when customers have certain faith in a brand, they tend to use it and feel content and afterward become loyal to that brand, but even if they have no faith, it may be the impulse, payment capability, or other customers' shopping situations that have effect on their own.

\section{Conclusion and recommendations}

\subsection{Conclusion}

The paper has attained its goal of systemizing the theoretical bases on brand experience in general and fashion brand experience in particular. In spite of the originality of the research in this domain, its findings achieve a few objectives of generalizing its conceptual framework in the field of fashion retail. Moreover, we have verified the reliability of the scales as well as the suitability of the research model in accordance with the context of Vietnam, and the results act in line with those of earlier studies carried out in other countries. The paper, all the same, reveals a few limitations as below:

Firstly, the survey was conducted on the two famous brands (Ninomax and Blue Exchange) in Danang, which places certain restrictions on the scope of this study. Future research, hence, should consider expanding the scope for further effectiveness.

Secondly, the target customers of the two fashion brands are aged between 18 and 35, a fairly young age range with limited consumer experience and brand experiences. Further research may target the retail industry in general to verify the suitability of both the scales and model with various age groups.

\subsection{Recommendations}

For the marketers in the retail business in general and fashion retail business in particular, it is necessary to consider customers' brand experiences. 
Creating sensory experience: Visual attraction shall be exerted through color usage, product display, and product designs of which fashion retailer should take notice.

Creating affective, intellectual, and relational experiences: Fashion retail businesses should emphasize the training of salespersons, consultants, and customer relations staff, who are supposed to keep in touch with customers and receive their feedback in a thoughtful manner. In this way their affection is gained, and a sufficient link between the brand and the customers themselves, established.

Creating product experience: Fashion brands need to think about the quality of their products, developed to provide pleasant feelings through fine material, durable color patterns, and well-suited design in harmony with the contemporary fashion trend so as to have customers fully enjoy their product experiences.

Creating shopping experience: Promoting consumption of the brand's products demands rapt attention to influential product exhibition in addition to user-friendly consultancy services and attentive sales staff in order to leave a favorable impression in consumers' interaction with the brand. Development of associated services to create fashion brand experiences such as efficient tailor services and promotional plans is vital to attract and maintain relations with customers.

Creating brand personality: Wearing a fancy set of clothes mostly reflects the personality of the wearer. For this reason brand personality should be cultivated to be uniquely perceived by customers, which can be realized through positive product experiences.

Sound practices implemented by fashion businesses that better offer those listed experiences will bring customer satisfaction with and/or loyalty to the established brand

\section{References}

Brakus, J. J., Smitch, B. H., \& Zarantonello, L. (2009). Brand experience: What is it? How is it measured? Does it affect brand loyalty? Journal of Marketing, 73(5), 52-68.

Chaudhuri, A., \& Holbrook, M. B. (2001). The chain of effects from brand trust and brand affect to brand performance: The role of brand loyalty. Journal of Marketing, 65, 81-93.

Choi, Y. G., Chihyung, O., Seon, S., \& Hyun. (2011). Evaluating relationships among brand experience, brand personality, brand prestige, brand relationship quality, and brand loyalty: An empirical study of coffeehouse brands. Retrieved from scholar works.umass.edu/graconf_hospitality/2011/ Presentation/22/ 
Evans, L. J. (2011). Fashion-brand experiences in multi-channel retailing: Impacts of experience dimensions and experience type on brand resonance. TX: University of North Texas.

Forney, J. C., Park, E. J., \& Brandon, L. (2005). Effects of evaluative criteria on fashion brand extension. Journal of Fashion Marketing and Management, 9(2), 156-165.

Gentile, C., Spiller, N., \& Noci, G. (2007). How to sustain the customer experience: An overview of experience components that co-create value with the customer. European Management Journal, 25(5), 395-410.

Hoch, S. J., \& Ha, Y.-W. (1986). Consumer learning: Advertising and the ambiguity of product experience. Journal of Consumer Research, 13(September), 221-233.

Horppu, M., Kulvalainen, O., Tarkiainen, A., \& Ellonen, H. K. (2008). Online satisfaction, trust and loyalty, and the impact of parent brand. Journal of Product \& Brand Management, 17(6), 403-413.

Kerin, R. A., Jain, A., \& Howard, D. J. (1992). Store shopping experience and consumer price-qualityvalue perceptions. Journal of Retailing, 68(4), 376-397.

Kim, H. J. (2012). The dimensionality of fashion-brand experience: Aligning consumer-based brand equity approach. Journal of Fashion Marketing and Management: An International Journal, 16(4), 418-441.

Kim, H. J., \& Lennon, S. J. (2010). E-atmosphere, emotional, cognitive, and behavioral responses. Journal of Fashion Marketing and Management, 14(3), 412-428.

Lee, K.-Y., Huang, H.-L., \& Hsu, Y.-C. (2007). Trust, satisfaction and commitment: On loyalty to international retail service brands. Asia Pacific Management Review, 12(3), 161-169.

Mano, H., \& Oliver, R. H. (1993). Assessing the dimensionality and structure of the consumption experience: Evaluation, feeling, and satisfaction. Journal of Consumer Research, 20(3), 451-466.

Nysveen, H., Pedersen, P. E., \& Siv, S. (2013). Brand experiences in service organizations: Exploring the individual effects of brand experience dimensions. Journal of Brand Management, 20(5), 404423.

Oliver, R. L. (1981). Measurement and evaluation of satisfaction processes in retail settings. Journal of Retailing, 57(3), 25-48.

Park, E. J., Kim, E. Y., \& Forney, J. C. (2006). A structural model of fashion-oriented impulse buying behavior. Journal of Fashion Marketing and Management, 10(4), 433-446.

Park, H. J., Burns, L. D., \& Rabolt, N. J. (2007). Fashion innovativeness, materialism, and attitude toward purchasing foreign fashion goods online across national borders. Journal of Fashion Marketing and Management, 11(2), 201-214.

Şahin, A., Zehir, C., \& Kitapçı. (2011). The effects of brand experiences, trust and satisfaction on building brand loyalty: An empirical research on global brands. In the proceedings of $7^{\text {th }}$ International Strategic Management Conference. Procedia - Social and Behavioral Sciences, 24, 1288-1301.

Schmitt, B. H. (1999). Experiential marketing: How to get customers to sense, feel, think, act, relate to your company and brands. NY: The Free Press.

Zhou, Z., Zhang, Q., Su, C., \& Zhou, N. (2012). How do brand communities generate brand relationships? Intermediate mechanisms. Journal of Business Research, 65(7), 890-895. 